\title{
Cornell Studies in Political Economy
}

\author{
Edited by Peter J. Katzenstein
}

Collapse of an Industry: Nuclear Power and the Contradictions of U.S. Policy, by John L. Campbell

Power, Purpose, and Collective Choice: Economic Strategy in Socialist States, edited by Ellen Comisso and Laura D'Andrea Tyson

The Political Economy of the New Asian Industrialism, edited by Frederic C. Deyo

Dislodging Multinationals: India's Strategy in Comparative Perspective, by Dennis J. Encarnation

Democracy and Markets: The Politics of Mixed Economies, by John R. Freeman

The Misunderstood Miracle: Industrial Development and Political Change in Japan, by David Friedman

Patchwork Protectionism: Textile Trade Policy in the United States, Japan, and West Germany, by $\mathrm{H}$. Richard Friman

Politics in Hard Times: Comparative Responses to International Economic Crises, by Peter Gourevitch

Closing the Gold Window: Domestic Politics and the End of Bretton Woods, by Joanne Gowa Cooperation among Nations: Europe, America, and Non-tariff Barriers to Trade, by Joseph M. Grieco

Pathways from the Periphery: The Politics of Growth in the Newly Industrializing Countries, by Stephan Haggard

The Philippine State and the Marcos Regime: The Politics of Export, by Gary Hawes

Reasons of State: Oil Politics and the Capacities of American Government, by G. John Ikenberry

The State and American Foreign Economic Policy, edited by G. John Ikenberry, David A. Lake, and Michael Mastanduno

Pipeline Politics: The Complex Political Economy of East-West Energy Trade, by Bruce W. Jentleson

The Politics of International Debt, edited by Miles Kahler

Corporatism and Change: Austria, Switzerland, and the Politics of Industry, by Peter J. Katzenstein

Industry and Politics in West Germany: Toward the Third Republic, edited by Peter J. Katzenstein

Small States in World Markets: Industrial Policy in Europe, by Peter J. Katzenstein

The Sovereign Entrepreneur: Oil Policies in Advanced and Less Developed Capitalist Countries, by Merrie Gilbert Klapp 


\section{Cornell Studies in Political Economy}

International Regimes, edited by Stephen D. Krasner

Power, Protection, and Free Trade: International Sources of U.S. Commercial Strategy, 18871939, by David A. Lake

State Capitalism: Public Enterprise in Canada, by Jeanne Kirk Laux and Maureen Appel Molot

Opening Financial Markets: Banking Politics on the Pacific Rim, by Louis W. Pauly

The Business of the Japanese State: Energy Markets in Comparative and Historical Perspective, by Richard J. Samuels

In the Dominions of Debt: Historical Perspectives on Dependent Development, by Herman M. Schwartz

Europe and the New Technologies, edited by Margaret Sharp

Europe's Industries: Public and Private Strategies for Change, edited by Geoffrey Shepherd, François Duchêne, and Christopher Saunders

Fair Shares: Unions, Pay, and Politics in Sweden and West Germany, by Peter Swenson

National Styles of Regulation: Environmental Policy in Great Britain and the United States, by David Vogel

International Cooperation: Building Regimes for Natural Resources and the Environment, by Oran R. Young

Governments, Markets, and Growth: Financial Systems and the Politics of Industrial Change, by John Zysman

American Industry in International Competition: Government Policies and Corporate Strategies, edited by John Zysman and Laura Tyson 


\title{
Power, Protection, and Free Trade
}

\author{
INTERNATIONAL SOURCES OF \\ U.S. Commercial STRATEgy, 1887-1939 \\ DAVID A. LAKE
}

Cornell University Press

Ithaca and London 
Open access edition funded by the National Endowment for the Humanities/ Andrew W. Mellon Foundation Humanities Open Book Program.

\section{Copyright (C) 1988 by Cornell University}

All rights reserved. Except for brief quotations in a review, this book, or parts thereof, must not be reproduced in any form without permission in writing from the publisher. For information, address Cornell University Press, Sage House, 512 East State Street, Ithaca, New York 14850, or visit our website at cornellpress.cornell.edu.

First published 1988 by Cornell University Press

First published, Cornell Paperbacks, 1990

Library of Congress Cataloging-in-Publication Data

Lake, David A.

Power, protection, and free trade.

(Cornell studies in political economy)

Includes index.

1. United States - Commercial policy-History. 2. International economic relations. 3. Free trade and protection-History. I. Title. II. Series.

HF1455.L34 $1988 \quad 382^{\prime} .3^{\prime} 0973 \quad 87-47869$

ISBN-13: 978-0-8014-2134-1 (cloth) — ISBN-13: 978-0-8014-9753-7 (pbk.)

The text of this book is licensed under a Creative Commons

Attribution-NonCommercial-NoDerivatives 4.0 International License:

https://creativecommons.org/licenses/by-nc-nd/4.0/ 
To Wendy, with love 
